EARLY DISCOVERERS

$\mathrm{XXIX}$

\title{
EARLY REGORD AND INTERPRETATION OF ICE-WEDGE PSEUDOMORPH IN COUNTY LONDONDERRY, NORTHERN IRELAND, BY J. R. KILROE
}

\author{
By Eric A. Colmoun \\ (Department of Geography, Trinity College, University of Dublin, Dublin 2, Eire)
}

Some of the geologists employed with the Geological Survey of Ireland during the primary survey of the country between 1845 and I 914 were very accurate observers and made early records of several kinds of phenomena. These records received very little publicity in academic circles owing to their inclusion in the Memoirs of the Geological Survey which are usually only consulted by personnel who are doing research in Ireland. J. R. Kilroe was employed with the Geological Survey of Ireland between ${ }^{2} 874$ and ${ }_{19} I_{3}$, and he had a particular interest in the mapping and interpretation of glacial and associated drift deposits. During 1905-08 he was engaged, with others, on the mapping and preparation of "The geology of the country around Londonderry" (Wilkinson and others, r 908 ).

During this survey, Kilroe observed what he termed a "gravel dyke" in the surface layers of the outwash sands and gravels on the eastern flank of the Foyle Valley at Caw Townland (C.46I I8I).* Kilroe provided a sketch drawing of a photograph on page 62 of the Londonderry Memoir which indicated clearly that the gravel dyke was an ice-wedge pseudomorph. He commented that the dyke of gravel was produced by infilling from above of a fissure which once vertically traversed the stratified sand and gravel. He observed that the gravel dyke truncated the layers of cross stratification and bedding of the outwash sands and gravels, and concluded that the sides of the fissure must have been perfectly even when the fissure was filled with gravel. He argued that such an even contact between the fissure margin and the beds of outwash sand and gravel, and the insertion of the gravel fill from above with no regard for the bedding of the deposits, was alone consistent with the layers having been frozen at the time of emplacement. Thus, he envisaged that the gravel dyke was formed in frozen outwash deposits during the final deglaciation of the area when seasonal floods, carrying gravel, still moved over the outwash plain from time to time.

This observation, and very good deductive interpretation, is of considerable historic interest as it pre-dates the classic interpretation of ground-ice wedges in Alaska published by Leffingwell (I9I5, I9I9). Though the presence of permanently frozen ground was quite widely known in Arctic regions, its former widespread occurrence in temperate latitudes was only beginning to be appreciated. Though Kilroe did not state that the space occupied by the gravel dyke was formerly filled with a wedge of ground ice, his clear description and interpretation of the gravel dyke as being associated with frozen ground is probably the earliest record in the British Isles of the association of the fossil casts of ice wedges with former permafrost conditions.

Recent investigations of the glacial and periglacial landforms and deposits of a large part of County Londonderry and adjacent areas in Tyrone and north-east Donegal have confirmed the record of Kilroe, and more than 35 ice-wedge pseudomorphs are now known from the surface layers of morainic and outwash sands and gravels of this area. The wedges vary between $\mathrm{I}$ and $4 \mathrm{~m}$ in depth and begin at the base of the post-glacial soil profile. They are

* Londonderry Sheet 2, Ordnance Survey of Northern Ireland, third series, 1 : 63360. 
associated with former conditions of widespread permafrost and the development of a seasonally active layer that extended to a depth of 1.5 to $2 \mathrm{~m}$. The ice wedges probably existed during the final phase of deglaciation, during pollen zone I times, but they could also have been formed during the succeeding cold periglacial conditions of pollen zone III times (Colhoun, in press).

MS. received 4 February 1970

\section{REFERENCES}

Colhoun, E. A. In press. Late Weichselian periglacial phenomena of the Sperrin Mountains, Northern Ireland. Proceedings of the Royal Irish Academy, Vol. 71 B 3 .

Leffingwell, E. de K. 1915. Ground-ice wedges. The dominant form of ground-ice on the north coast of Alaska.

Fournal of Geology, Vol. 23, No. 7, p. 635-54:
Leffingwell, E. de K. 1919. The Canning River region, northern Alaska. U.S. Geological Survey. Professional Paper rog.

Wilkinson, S. B., and others. 1908. The geology of the country around Londonderry, by S. B. Wilkinson, A. McHenry, J. R. Kilroe and H. J. Seymour. Memoirs of the Geological Survey. Ireland. 